\title{
Between a Rock and a Hard Place: An Epigenetic-Centric View of Testicular Germ Cell Tumors
}

\author{
Ratnakar Singh (D), Zeeshan Fazal (D), Sarah J. Freemantle and Michael J. Spinella * \\ Department of Comparative Biosciences and the Carle Illinois College of Medicine and the Cancer Center of \\ Illinois, University of Illinois at Urbana-Champaign, Urbana, IL 61801, USA; rsingh02@illinois.edu (R.S.); \\ fazal2@illinois.edu (Z.F.); sarahf@illinois.edu (S.J.F.) \\ * Correspondence: spinella@illinois.edu
}

Citation: Singh, R.; Fazal, Z.;

Freemantle, S.J.; Spinella, M.J.

Between a Rock and a Hard Place: An Epigenetic-Centric View of Testicular Germ Cell Tumors. Cancers 2021, 13, 1506. https://doi.org/10.3390/ cancers13071506

Academic Editors: Beate Köberle and Giuseppe Di Lorenzo

Received: 16 February 2021

Accepted: 22 March 2021

Published: 25 March 2021

Publisher's Note: MDPI stays neutral with regard to jurisdictional claims in published maps and institutional affiliations.

Simple Summary: This minireview focuses on the role of epigenetics in testicular cancer. A working model is developed that postulates that epigenetic features that drive testicular cancer malignancy also enable these tumors to be cured at a high rate with chemotherapy. Chemoresistance may occur by epigenetic uncoupling of malignancy and chemosensitivity, a scenario that may be amenable to epigenetic-based therapies.

Abstract: Compared to many common solid tumors, the main genetic drivers of most testicular germ cell tumors (TGCTs) are unknown. Decades of focus on genomic alterations in TGCTs including awareness of a near universal increase in copies of chromosome 12p have failed to uncover exceptional driver genes, especially in genes that can be targeted therapeutically. Thus far, TGCT patients have missed out on the benefits of targeted therapies available to treat most other malignancies. In the past decade there has been a greater appreciation that epigenetics may play an especially prominent role in TGCT etiology, progression, and hypersensitivity to conventional chemotherapy. While genetics undoubtedly plays a role in TGCT biology, this mini-review will focus on the epigenetic "states" or features of testicular cancer, with an emphasis on DNA methylation, histone modifications, and miRNAs associated with TGCT susceptibility, initiation, progression, and response to chemotherapy. In addition, we comment on the current status of epigenetic-based therapy and epigenetic biomarker development for TGCTs. Finally, we suggest a unifying "rock and a hard place" or "differentiate or die" model where the tumorigenicity and curability of TGCTs are both dependent on common but still ill-defined epigenetic states.

Keywords: testicular cancer; epigenetics; embryonal carcinoma; cisplatin; resistance; testicular germ cell tumors; DNA methylation

\section{Introduction}

Human germ-cell tumors are a heterogeneous group of neoplasms, which occur in the gonads, both the ovaries and the testes, and in distinct extragonadal sites along the midline of the body and brain [1]. Approximately 90-95\% of testicular cancers correspond to pathologies originating from the germ cell lineage called testicular germ cell tumors (TGCTs) [2]. In 2016, the World Health Organization (WHO) reported a comprehensive classification system for TGCTs that considers the germ cell involved, the embryonic and extra-embryonic lineages present, the histological composition of the tumor and the developmental potential of the cell of origin [3]. Based on this classification system, TGCTs are divided into two main groups (i) tumors derived from germ cell neoplasia in situ (GCNIS); and (ii) tumors considered not to be derived from GCNIS [3,4]. GCNIS related TGCTs (also known as type II TGCTs) occur in adolescents and young adults and are histologically subdivided into seminoma and nonseminoma (that is, embryonal carcinomas, teratomas, yolk sac tumors and choriocarcinomas) that can be pure or intermixed. Non-GCNIS related TGCTs include mainly pediatric or prepubertal tumors (also known as 
type I TGCTs) that include benign teratoma and malignant yolk sac tumors, and spermatocytic tumors of the testis (also known as type III TGCTs) that predominantly affect men $>50$ years old [5].

TGCTs are rare solid tumors which account for $1 \%$ of cancers in men, but the most common solid malignancy of young males between the ages of 15 and 44 years [6]. The incidence of TGCTs has been steadily rising in young males $[7,8]$. Recent statistics estimated that TGCTs have the largest number of new cases among all cancers for males under the age of 34 years in the USA and second largest worldwide [6]. The incidence of TGCTs varies widely with geographic location with the highest incidence in northern European countries and the lowest in African nations [8]. The reasons for these differences are not known but are hypothesized to involve a combination of inherited and environmental factors including exposure to endocrine disruptors in utero [2,9].

In general, TGCT treatment is highly successful. Testicular cancer prognosis is generally favorable, particularly in high-income countries [10]. Mortality rates are higher in low-incident and low-income countries compared to high-incident, high-income countries [11]. Patients diagnosed with a non-metastatic TGCT have a five-year survival of $\geq 95 \%$ [6]. Furthermore, metastatic testicular cancer can be cured with conventional cisplatin-based therapy at a rate approaching $80 \%$ while most common solid tumors are fatal in the metastatic setting $[12,13]$ However, $30 \%$ of TGCT patients are refractory or develop resistance to cisplatin-based therapy and approximately $50 \%$ of these patients die from progressive disease $[14,15]$. There is a clinical need for new more targeted approaches for TGCTs for the treatment of cisplatin refractory disease and for the avoidance of cisplatin related toxicities which can be significant and lifelong [16-19].

TGCTs are at the crossroads of developmental and neoplastic processes $[2,5,20]$. TGCTs are characterized by substantial histological heterogeneity, despite a uniform cytogenetic profile including uniform chromosomal 12p amplifications [21]. The etiology of TGCTs is uncertain compared to many somatic cancers [22,23]. In general, the low frequency of somatic mutations in TGCTs, especially in nonseminomas compared to other cancers, suggest that epigenetic mechanisms play an especially prominent role in their pathogenesis $[24,25]$. TGCTs also possess distinct epigenetic states compared to somatic cancers that reflect their primordial germ cell (PGC) origins that underlie the unique biology of these tumors, including their curability [2,26-28]. Distinct epigenetics may render TGCTs distinctly susceptible to epigenetic targeted therapies [29-32].

In this mini-review, we summarize the main epigenetic features of testicular cancer, with a focus on DNA methylation, histone modifications, and miRNAs and their involvement in testicular carcinogenesis and response to chemotherapy. In addition, we address the current status of epigenetic-based therapy and epigenetic biomarker development for TGCTs. Finally, we suggest a unifying model where the tumorigenicity and curability of TGCTs are both dependent on common but still ill-defined epigenetic states.

\section{Risk Factors and Pathogenesis of TGCTs}

The etiology of TGCTs is still largely unknown [1,2]. Despite a strong familial hereditary component, robust genetic germline risk alleles have not been found for TGCTs [33]. However, several low penetrant, inherited germline alleles have been identified including KITGL, SPRY4, and BAK1 suggesting a polygenetic nature to TGCT risk [34-45]. Interestingly, some of these risk alleles are also associated with regulating epigenetics or germ cell differentiation. The incidence of TGCTs, once extremely rare, has increased significantly and steadily, especially in industrialized nations suggesting a potential role for environmental toxicants [6-8]. For example, the annual number of TGCT cases has doubled worldwide since the 1950s and continues to rise [6-8]. Several features predict impact from the microenvironment of male germ cell development, including cryptorchidism, hypospadias, prior testicular cancer, impaired spermatogenesis, a family history of testicular cancer, Down's syndrome, low birth weight, premature birth, birth order, bleeding during pregnancy, estrogen exposure during pregnancy, high maternal age, and neonatal 
jaundice that are proposed risk factors for TGCTs (Figure 1) [46-56]. Associations and co-occurrences of two or more factors in the same individual and at the population level has led to the hypothesis that a testicular dysgenesis syndrome (TDS), likely originating in utero, is a key predisposing factor for testicular cancer [57,58]. The increased incidence of TDS is suggested to be associated with exposure to environmental agents such as endocrine disrupters and certain toxic industrial chemicals. Sex steroid hormones (especially androgens) have an important role in urogenital development. Studies have suggested that an in utero hormonal disturbance increases the risk of TGCTs [59-61]. A substantial proportion of germline, genetic disorders of sex development (DSD), associated with fetal androgen insufficiency, are also associated with increased risk of germ cell malignancy [62,63]. The recent realization that environmental factors likely play a significant role in the pathogenesis of testicular cancer has led to a "genvironmental" model suggests that an interaction between environmental factors (that mediate epigenetic changes) and genetic alterations can explain the shifting epidemiology of TGCTs and its intricate association with DSD and TDS [64] (Figure 1).

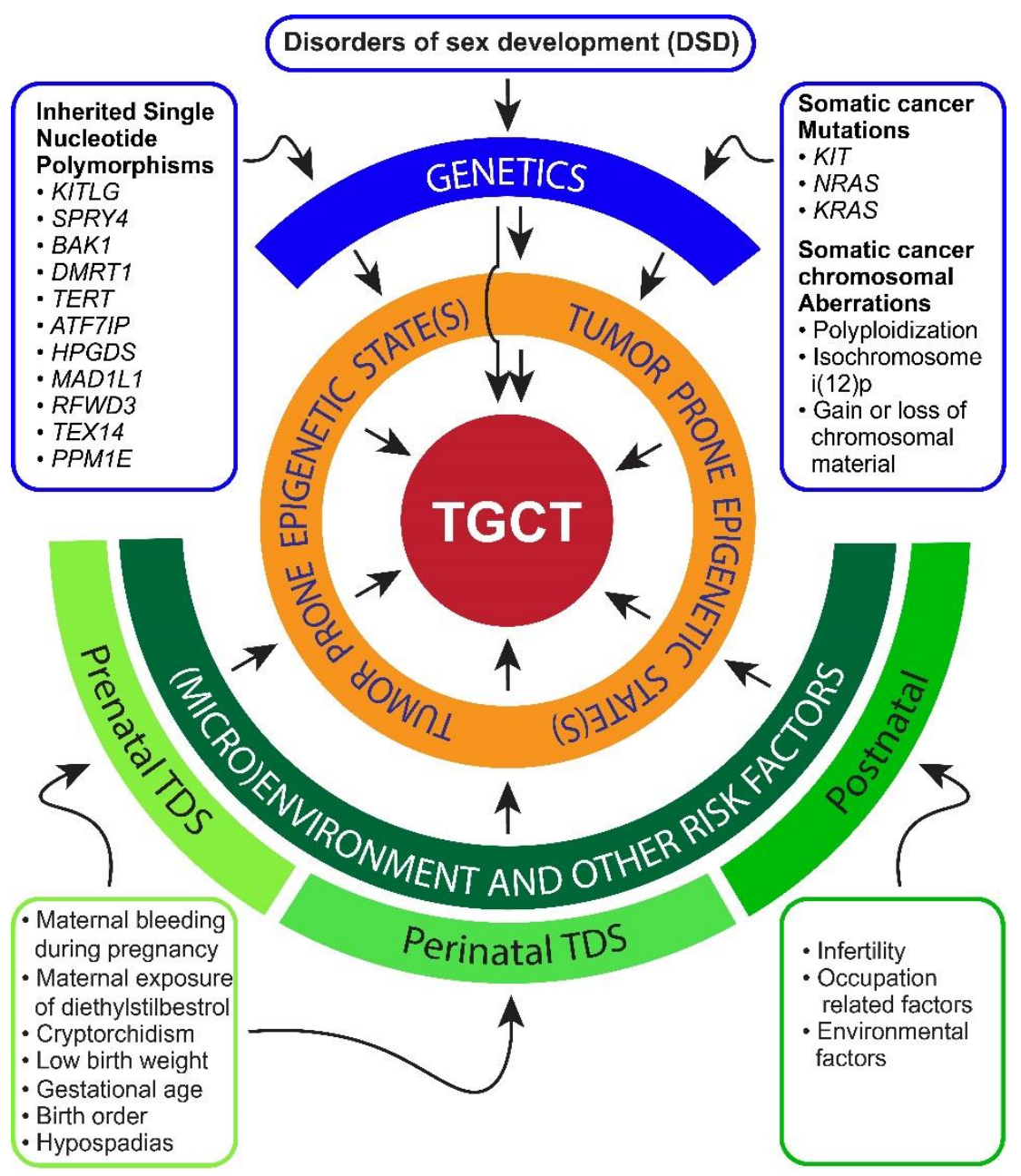

Figure 1. An epigenetic-centric view of testicular germ cell tumors (TGCT) etiology. While genetics undoubtedly play a role in TGCT development, epigenetic altering factors in the microenvironment of the testis from both internal and external sources may be a more important driving factor. The model also suggests that even inherited genetic germline variants and somatic cancer alterations may participate in establishing tumorigenic epigenetic state(s) of TGCTs. DSD, disorders of sex development, TDS, testicular dysgenesis syndrome.

Primordial germ cells (PGCs), precursors of sperm and eggs, generate a new organism that is capable of creating endless new generations. Defects in PGC differentiation lead to 
germ cell tumors $[20,65]$. Under normal conditions PGCs further differentiate and form gonocytes [66]. Arrested gonocytes that fail to mature to spermatogonia lead to the tumors of young adults (seminomas and non-seminomas) which are preceded by GCNIS [20,65]. GCNIS cells gradually acquire secondary somatic genomic changes and transform to malignant germ cells while adapting to the post-pubertal testis niche [67]. Due to common origins, GCNIS, seminoma and embryonal carcinoma (EC) have many morphological similarities with PGCs and early gonocytes. Expression of POU5F1 (OCT4) and NANOG, which are known for their association with pluripotency in embryonic stem cells are also characteristic of GCNIS and derived invasive testicular cancers [68]. Other markers, including placental-like alkaline phosphatase (PLAP), the stem cell factor receptor KIT, and TFAP2C (AP2 $\gamma)$ also provide evidence that GCNIS and its derived cancers are similar to PGCs [20,68]. Two characteristic secondary somatic chromosomal aberrations associated with GCNIS and derived TGCTs are polyploidization and amplification of chromosome 12, which often manifests as an isochromosome i(12)p [21,69]. Other secondary chromosomal abnormalities associated with TGCTs include gain of genetic material on chromosomes 1 , $2 p, 7,8,12,14 q, 15 q, 17 q, 21 q$, and $X$ and the deletion of genetic material from chromosomes $4,5,11 q, 13 q$, and 18q2 [21,69]. Similarly, multiple passaging of embryonic stem cells has been shown to result in acquired alterations similar to those found in TGCTs and $\mathrm{EC}$, including chromosome 12,17, and X gain [70]. Genome-wide sequencing indicates secondary somatic gain/amplification of $12 p$ in the majority of patients with gain in $12 q$, $8 \mathrm{q}, 22 \mathrm{q}$, and deletion/loss of 11q, 18q, 18p, 9p, 4q, 10q, 5q, 16q, and 19q also occurring with much less frequency $[24,25,71]$. Despite cytogenetic abnormalities the mutational burden of TGCTs are low compared to somatic cancers.

Somatic mutation in TGCTs are relatively rare and occur mostly in seminoma. Specific somatic mutations or amplifications in tumor DNA have been identified in a few genes, but only KIT, KRAS, and NRAS have been implicated repeatedly in different studies, mostly in seminomas $[24,25,71]$. Gain-of function somatic mutations in KIT have been detected in up to $25 \%$ of seminomas but are very rare in non-seminoma germ cell tumors [24,25,71]. Allelic inherited germline variation within KITLG, the gene encoding the ligand for KIT receptor is the strongest genetic risk factor for TGCTs [34]. Other rare inherited germline inactivating PDE11A variants are most likely associated with TGCTs of young adults [72]. Comparing somatic mutations in GCNIS and TGCTs suggest that genetic mutations are likely involved in progression of TGCTs rather than initiating events [73]. It is worth noting that TGCTs possess a high level of genomic instability, including aneuploidy and recurrent copy number changes that likely participate in tumor progression [24,25,71].

Endocrine disrupting chemicals that impair estrogen and androgen signaling during early development are associated with an increased risk of TGCTs. Some occupations, such as firefighting and aircraft maintenance also increase TGCT risk [74,75]. Testicular physiology is well characterized and known to be hormone sensitive. The impact of hormones on the testis is mainly through the androgen and estrogen receptors. Interestingly, some studies have explored the potential association of TGCTs with inherited single nucleotide polymorphisms of the androgen receptor (AR), the estrogen receptors (ER) and genes involved in either synthesis or degradation of gonadal hormones [76-79]. It is important to remember that potential epigenetic disruptions may not necessarily target PGCs/gonocytes directly but may alter the epigenetic state of the somatic cells of the testis, Leydig and Sertoli cells which produce growth factors and hormones necessary to maintain the proper micro-environment during spermatogenesis.

Thus, from an epigenetic-centric view, epigenetic perturbations that arrest PGC/gonocyte differentiation leading to tumorigenic prone states are dominant events downstream of the many risk factors outlined in this section including environmental exposures, inheritable genetic factors and developmental reproductive disorders predicted to alter the microenvironment of the developing germ cell (Figure 1). We contend that perhaps the majority of risk factors converge to favor a limited number of cancer driving epigenetic states that in some cases further progress due to somatic genetic mutations including 
those of KIT and KRAS. Many decades of focus on somatic genomic alterations in TGCTs including awareness of near universal increase in copies of chromosome $12 p$ have failed to uncover exceptional cancer driver genes. This at least suggests that an epigenetic mediated tumorigenic state or states may be the true driver of TGCTs.

\section{Mechanisms of Chemotherapy Sensitivity and Resistance in TGCTs}

A defining feature of metastatic TGCTs is a unique hypersensitivity to conventional chemotherapeutics especially to cisplatin-based therapies [12,13]. However, a clinically significant proportion of patients are resistant to cisplatin-based therapy and die from progressive disease $[14,15]$. This is in part due the lack of targeted therapies for TGCTs which is in turn likely due to a paucity of driver mutations or genomic alterations. Further, while the majority of TGCTs with advanced disease are cured with chemotherapy, this is associated with acute and lifelong toxicities in an exceptionally young patient population [16-19]. Hence there is a strong rationale to develop alternative and cisplatin-sparing therapies for TGCTs. Similar to etiology and initiation, the mechanisms responsible for TGCT chemosensitivity and resistance have been elusive and appear for the most part to be independent of acquired genetic mutations or alterations [29,80-82]. In this section we briefly review traditional mechanisms proposed to account for TGCT chemosensitivity and resistance.

Perhaps the most convincing mechanism for TGCT resistance due to acquired mutation is mutation of p53 or p53 compromised by increased MDM2 copy number. The p53 gene is notoriously wild-type in most TGCTs unlike the situation for other cancers. This presents a plausible mechanism to account for the hypersensitivity of TGCTs to chemotherapy. While genetic alterations in the p53 pathway do occur in cisplatin resistant cell models and in patients, the percentage is low and does not appear to explain the majority of cisplatin resistant disease [24,71,83-86]. Other suggested mechanisms of cisplatin resistance include alterations in PDGFR/PI3K/AKT/PTEN, IGF1R, Cyclin D1, p21, autophagy and apoptotic pathways [29,80-82]. Additional proposed mechanisms include alterations in cisplatin accumulation or increased inactivation of cisplatin by conjugation reactions [29,80-82]. The alterations in most of these cases involve expression level changes of pathway components and not fixed acquired mutations or copy number changes.

Another major proposed mediator of cisplatin resistance in TGCTs has been DNA repair and DNA damage response pathways, especially the nuclear excision repair (NER), base excision repair (BER), homologous recombination (HR) and mismatch repair (MMR) pathways [87-94]. This has led to studies suggesting that TGCTs may be vulnerable to PARP inhibitors $[95,96]$. Again, the argument has been that alterations mostly in the levels of DNA repair and DNA damage response (DDR) pathway components and not common genetic mutations result in either more efficient DNA repair or increased tolerance to DNA damage in cisplatin refractory TGCT cells. Interestingly expression levels of some of these components have been proposed to involve alterations in promoter DNA methylation, thus providing crosstalk between traditional DNA repair/DDR based mechanisms of chemotherapy resistance and epigenetic reprogramming in TGCTs [95,97].

In contrast with traditional/genomic mechanisms of chemoresistance a relatively unexplored explanation involves epigenetics. In an epigenetic-centric view of TGCTs one would postulate that even traditional mechanisms of chemotherapy resistance like dysregulation of the DNA repair and the DNA damage response could in actuality be downstream consequences of altered epigenetic states that provide, for example, more efficient DNA repair or increased tolerance of cellular DNA damage.

\section{Epigenetic States in Testicular Germ Cell Tumors Associated with Tumorigenicity and Chemosensitivity}

Despite involvement of genetic factors, TGCTs are clearly not a disease of accumulating mutations like most solid tumors, and again unlike most cancers, genetic alterations appear to poorly explain the initiation and the unique curability of TGCTs. The paucity of actionable driver mutations in TGCTs suggests that a number of as yet poorly characterized genetic 
states may mediate key aspects of tumorigenicity and chemotherapy response in TGCTs. In this section we briefly review recent findings related to epigenetic states of TGCTs.

Epigenetic regulation of gene expression takes places at the protein level (posttranslational histone modifications), DNA level (DNA methylation), and RNA level (noncoding RNAs). These epigenetic modifications can create a compact chromatin structure (heterochromatin, which is transcriptionally silent) or an open chromatin structure (euchromatin, which is transcriptionally active). These changes in gene expression are known to be influenced by chemical modifications on histone tails or DNA. The most studied epigenetic modifications include DNA methylation, histone acetylation and histone methylation. Dynamic epigenetic changes occur during the male germ cell cycle. PGCs and gonocytes in the male gonad have undergone epigenetic reprogramming which includes erasure and re-establishment of DNA methylation and alterations in histone modifications [98]. Patterns of DNA methylation and histone modifications in TGCTs are distinct from those in somatic cancers and show developmental patterns $[20,27]$. The third mechanism involved in regulation of gene activity is RNA interference targeting specific mRNA molecules at the posttranscriptional level. Small RNAs, including microRNAs (miRNAs), endogenous small interfering RNAs (endo-siRNAs) and PIWI-interacting RNAs (piRNAs) that may to be involved in the control of male germ cell differentiation may also participate in TGCTs carcinogenesis and chemosensitivity $[99,100]$. Distinct epigenetic states have also been associated with subtype identity and cisplatin resistance in TGCTs [25,101,102].

\subsection{Differentiation}

While the focus on epigenetics has been relatively recent, the relationship between differentiation, tumorigenicity, and chemosensitivity of TGCTs is well established. Specifically, it is well recognized that the degree of pluripotency or stem-like properties of TGCT histological subtypes roughly correlates with chemosensitivity, with seminoma and EC being the most chemosensitive followed by yolk sac, choriocarcinoma and immature teratoma with intermediate chemosensitivity followed by chemotherapy resistant, mature teratoma $[29,80]$. Differentiation status of TGCTs is presumed to be driven by epigenetic mechanisms. For example, DNA methylation but not genomic content tracks with differentiation and chemotherapy sensitivity (see below). During chemotherapy of advanced malignant TGCTs often all that remains is benign non-malignant teratoma resistant to cisplatin therapy [103]. Several clinical, animal, and cell line studies have shown a correlation between pluripotency markers OCT4 and NANOG and the degree of TGCT cisplatin sensitivity [104-107]. Hypoxia and cisplatin treatment of TGCT cells induce OCT4 repression and cisplatin resistance, in one instance correlating with OCT4 regulation of p21 via miR106b $[108,109]$. Experimentally induced differentiation of (embryonal carcinoma (EC) cells by retinoic acid or depletion of OCT4 also results in cisplatin resistance, further suggesting a tight link between pluripotency and chemosensitivity of TGCTs [104-107]. Retinoic acid induced differentiation has also been associated with down regulation of antitumor proteins EIR3, NOXA, and PUMA associated with cisplatin resistance [110]. There have also been studies demonstrating epigenetic mediated conversion of seminoma to nonseminoma in a seminoma cell line xenograft [111].

The stem cell of TGCTs, EC, have distinct properties compared to cancer stem cells in other solid tumors. Cancer stem cells in somatic tumors are often resistant to chemotherapy while the pluripotency of EC cells is associated with driving TGCT curability. This distinction is again likely driven in part by the unique epigenetic status of EC and seminoma. While other cancer stem cells have been suggested to possess stem cell properties including the expression of pluripotency markers including OCT4 and NANOG, EC are truly pluripotent and both EC and seminoma express OCT4, NANOG and other pluripotency markers orders of magnitude higher than somatic cancer stem cells [112]. 


\subsection{DNA Methylation}

DNA methylation is the most studied epigenetic mark in TGCTs and there is relatively strong evidence that DNA methylation is differentially distributed among the histologically distinct subtypes of TGCTs and among cisplatin sensitive and resistant tumors. As described above, TGCTs are believed to arise from PGCs or gonocytes, the stage in germ line development where DNA methylation and parental imprints are erased and totipotency is restored [98]. DNA methylation is an important regulator of gene transcription. Its role in carcinogenesis and chemoresistance has been a topic of considerable recent interest. The methylation of DNA is a major event during germ cell development and differentiation in retrotransposons, repeated regions, and differentially methylated regions (DMRs) of genes.

DNA methylation has been recognized as an important mechanism during TGCT progression and chemosensitivity [113-116]. TGCT genomic DNA is hypomethylated in comparison to most solid tumors. Like PGCs, GCNIS and seminomas display global DNA hypomethylation $[25,101,102]$. In contrast, teratomas display CpG methylation levels comparable with somatic tumor entities, while EC possess an intermediate level of $\mathrm{CpG}$ methylation and also uniquely possess non-CpG methylation similar to embryonic stem cells $[25,101,102]$. Methylome studies in TGCTs have shown that GCNIS, seminomas and nonseminomas are consistently demethylated in repetitive LINE1 elements and at imprinted genes and the XIST locus $[25,101,102,117]$. GCNIS and seminomas are also demethylated at ALU elements while ALU elements are partially methylated in nonseminoma $[25,101,102]$. Furthermore, locus specific promoter methylation occurs in nonseminoma that is distinct for each histological type, again with a general pattern of increased methylation with increased differentiation status [25,101,102]. This includes evidence that methylation of such genes as CRIPTO, HOXA9 MGMT, RASSFIA, SCGB3A1, CALCA, MMP9, CSFR1, and PTPRC is associated with distinct TGCT subtypes or poor prognosis [101,114-116,118].

There is evidence to suggest that hypermethylation of TGCTs especially EC and other nonseminoma subtypes may be associated with cisplatin resistance. Several specific gene promoters and differentially methylated regions (DMRs) have been associated with inherent and acquired cisplatin resistance in TGCTs and cell lines including RASSF1A, HIC1, $M G M T$, and CALCA [113-116]. Additionally, cisplatin treatment has been shown to be associated with increased DNA methylation in vivo [114]. Expression levels of DNMTs and TET enzymes responsible for adding and removing DNA methylation have been shown to be dynamically regulated and associated with clinical outcomes in TGCTs $[119,120]$.

Utilizing a series of isogenic cisplatin-resistant cell models we demonstrated a strong association between cisplatin resistance in TGCT cells and a net increase in global CpG and non-CpG DNA methylation spanning regulatory, intergenic, genic, and repeat elements [113]. Integrative transcriptome and methylome analyses revealed a strong negative correlation between gene promoter and $\mathrm{CpG}$ island methylation and gene expression in resistant cells. A bidirectional shift between gene promoter and gene body DNA methylation occurred within multiple genes that was associated with upregulation of polycomb targets and downregulation of tumor suppressor genes [113]. These findings suggest that global remodeling of DNA methylation is a key factor in mediating cisplatin hypersensitivity and that chemoresistance of TGCTs is mediated by a complex interplay between DNA methylation and the polycomb pathway (see below) [113].

In the epigenetic centric view, the unique epigenetic states of TGCTs may not only be responsible for tumorigenicity and chemosensitivity but may also be exploitable as therapeutic targets. In this regard DNA methyltransferase inhibitors have been furthest advanced. We and others have shown that EC cells are hypersensitive to the DNA methyltransferase inhibitors decitabine, azacytidine, guadecitabine, and MLo1302 in vitro and in vivo compared to somatic tumors [121-126]. This hypersensitivity extends to cisplatin refractory EC and is dependent on high levels of the DNA methyltransferase, DNMT3B [121-125]. Importantly, pretreatment of cisplatin refractory cells in vitro and in vivo could resensitize to cisplatin and this activity was associated with activation of p53 targets and a 
stress response, repression of pluripotency genes, and activation of genes repressed by DNA methylation [121-125]. A seminoma cell line was also sensitized to cisplatin after azacytidine treatment [115]. This data provided the rationale to combine cisplatin and guadecitabine in a phase Ib study of heavily pretreated cisplatin-resistant TGCT patients [NCT02429466]. This combination was tolerable and showed two major responses and an overall clinical benefit rate of $46 \%$ from 14 patients [127].

\subsection{Histone Modifications}

Compared to DNA methylation, relatively less is known concerning histone modifications in TGCTs. There is some data to suggest that like pluripotent embryonic stem and induced pluripotent stem cells, TGCTs and especially EC, may have high levels of bivalent histone marks H3K27me3 and H3K4me3 [128,129]. Bivalent marks are proposed to define genes that are poised to be either activated or permanently silenced upon differentiation $[128,129]$. This predicts that TGCT subtypes that are more differentiated will have a decrease in bivalency. While studies characterizing the actual genome-wide distribution of histone marks in TGCTs are lacking, there have been a number of studies assessing the expression of various histone writers, erasers and readers and related studies suggesting these expression levels may be exploited therapeutically [30-32,120,130]. In general, and as with DNA methylation inhibitors, there is evidence that TGCT cells may be especially sensitive to histone targeting drugs due to their pluripotent nature and that the resultant anticancer effects are multifactorial and include an apoptosis/stress response, alterations in gene expression and differentiation, and loss of pluripotency $[30-32,120,130]$.

The HDAC inhibitors belinostat and panobinosat among others have antitumor effects in both cisplatin sensitive and resistant EC cell lines and xenografts [131,132]. In vitro and in vivo antitumor effects in cisplatin resistant TGCT cell lines were also demonstrated for the dual HDAC and cytoskeletal inhibitor, animacroxam [133]. Interestingly, the HDAC inhibitor romidepsin was shown to cause toxicity at low doses in cisplatin resistant and sensitive EC and seminoma cells but not in fibroblasts or Sertoli cells and effects were associated with the regulation of the SWI/SNF-complex member, ARIDIA [134,135]. The seminoma cell line Tcam-2 was sensitive to the HDAC inhibitor depsipeptide [136].

Apart from HDAC inhibitors, EC and seminoma cells are also sensitive to the bromodomain inhibitor JQ1 and inhibitors of LSD1, a H3K4 demethylase [137,138]. Interestingly, TGCTs, especially seminoma, overexpress LSD1 [137]. We showed by RNA-seq and gene set enrichment analysis that a panel of isogenic cisplatin resistant EC lines have a dramatic enrichment in genes normally repressed by H3K27me3 and the polycomb repressive complex which correlated with a substantial decrease in global H3K27me3 and decreased expression of EZH2 and BMI1 [139]. Importantly, repression of H3K27 methylation with the EZH2 inhibitor GSK126 conferred cisplatin resistance to parental cells while induction of H3K27 methylation with the histone lysine demethylase inhibitor GSKJ4 resulted in increased cisplatin sensitivity to resistant cells, suggesting that the polycomb pathway is involved in the regulation of cisplatin sensitivity of TGCT cells [139]. As stated above, follow up analysis of these cisplatin resistant models suggest the same polycomb target genes are coordinately regulated by both H3K27 methylation and DNA methylation [113]. In summary, studies on epigenetic targeting of TGCTs suggest that tumorigenicity in this pluripotent, germ cell context may be especially vulnerable to epigenetic alterations compared to somatic cancers.

\subsection{Non-Coding RNA}

A third major epigenetic pathway, non-coding RNA, is a largely unexplored area in TGCT research but has the potential to provide insight on TGCT biology and to provide potential therapeutic targets. Most of the progress so far is in the area of biomarkers since it is clear that TGCTs overexpress unique non-coding RNAs, for reviews see [140,141]. For example, a highly promising miRNA, miR371a-3p is poised to enter the clinic alone or in combination with other miRNAs as a plasma biomarker of TGCT burden since 
strong evidence suggests superior sensitivity and specificity compared to standard-ofcare serum biomarkers AFP and hCG $[140,141]$. Similar to chromosome 12p, miR371a-3p appears pathognomonic for TGCTs, but also like 12p (first discovered in the 1980s) its functional role is very poorly understood. Studies have also explored whether miRNAs could be used to detect GCNIS or discriminate between malignant TGCT and benign teratoma [141-143]. However, despite this progress, the functional role of these TGCTspecific miRNAs is very poorly understood, although a few pioneering studies on a handful of miRNAs have explored functional roles including the finding that miR-372 and miR-373 neutralized p53 function through inhibition of the tumor suppressor LATS2 in TGCT cells [144-147]. Another form of non-coding RNA is the PIWI pathway that has a physiologic role in male germ cells. There is evidence that the PIWI pathway is altered/abrogated in TGCTs, although more work will be required to precisely define these alterations and their functional roles [99,100].

In summary, the epigenetic states of TGCTs and their association with key aspect of their biology, tumorigenicity, pluripotency, and sensitivity and resistance to chemotherapeutics are really just beginning to be appreciated. A complete and more precise understanding will be required to fully utilize epigenetics as tools and therapeutic targets in TGCT clinical medicine.

\section{Rock and a Hard Place Model}

Although there is still much to learn about the potentially unique role of epigenetics in TGCTs we have developed a "rock and a hard place" or "differentiation or die" model of TGCT epigenetic states that could be consistent with both the suspected origins of TGCTs and their unique curability (Figure 2). This model predicts that TGCTs are unique compared to other solid tumors in that the very epigenetic state that drives tumorigenicity of TGCTs is the same epigenetic state that drives chemosensitivity to cisplatin. In other words, the epigenetic state driving tumorigenesis of TGCTs is coupled to the epigenetic state driving chemosensitivity. This epigenetic state is likely complex and involves both distinct global DNA methylation status, H3K27me3, and H3K4me3 status (bivalency status) and other epigenetic mechanisms like miRNA, histone acetylation, and chromatin remodeling complexes. These epigenetic mechanisms are likely also intimately interconnected and involve reciprocal regulations of shared genomic regions.

The model predicts that there are two main outcomes or "default pathways" for cisplatin treated TGCTs. The most common pathway is apoptotic death due to the increased chemosensitivity directly attributed to the epigenetic state. The second default pathway is for the epigenetic state to adjust under selective pressure to afford resistance to cisplatin. However, since for TGCTs the epigenetic state of tumorigenicity is linked to the epigenetic state of chemosensitivity, this results in simultaneous loss of tumorigenicity. This can take the form, for example, of the differentiation seen in a subset of patients that present with benign cisplatin resistant teratoma after cisplatin therapy (Figure 2). In a small subset of TGCT patients a rare event occurs. Similar to the baseline situation for most other solid tumors, the factors driving tumorigenesis of TGCTs have now become uncoupled from the epigenetics driving chemosensitivity. In this case TGCT tumorigenicity is no longer comprised in the setting of cisplatin resistant. In this scenario seminoma that is generally less prone to cisplatin resistance compared to nonseminoma would be less prone to uncoupling. 


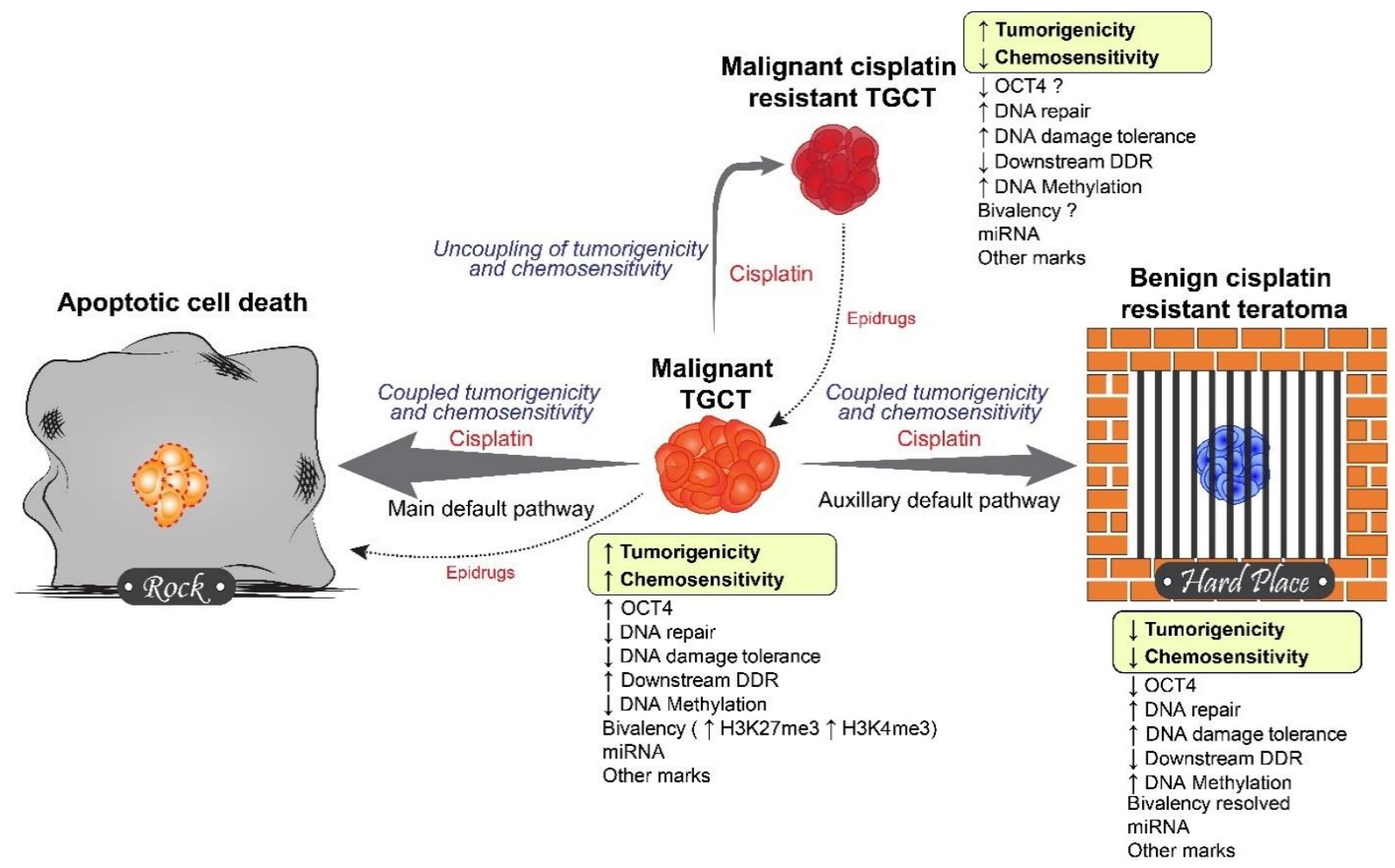

Figure 2. Rock and a hard place model of TGCT chemosensitivity. The model speculates that an explanation for why TGCTs are so sensitive to cisplatin-based therapy compared to other solid tumors is that the very epigenetic state(s) that drives tumorigenicity are the same or "linked" to the epigenetic state(s) that drive chemosensitivity. In such a model there are two main outcomes for cisplatin treated TGCTs; to either die or differentiate (in the extreme case to benign teratoma). This situation is predicted not to occur in other solid tumor types, or their cancer stem cells. In rare cases the epigenetic state driving tumorigenicity of TGCTs becomes uncoupled from the epigenetic state driving chemosensitivity resulting in cisplatin resistant TGCTs that retain tumorigenicity. Epigenetic drugs have the potential to "recouple" chemosensitivity with tumorigenicity or to target unique epigenetic vulnerabilities of TGCTs directly. Epigenetic drugs that cause teratoma formation would not be optimal as teratoma is still a clinical issue necessitating surgical removal.

What constitutes the coupling mechanism? There are several possibilities. There are many recent findings suggesting that the epigenetic chromatin context can directly influence the efficiency of DNA repair, the DNA damage response and DNA damage tolerance of cells [148-150]. Hence, the very epigenetic context that affords pluripotency (linked to tumorigenicity in TGCTs) also is the epigenetic state most sensitive to DNA damage. Other more direct mechanisms involve epigenetic regulation of components of the DNA repair and DNA damage response pathways. For example, DNA promoter methylation of $B R C A 1, R A D 51, M L H 1$, and MGMT has been shown to occur in and to influence chemosensitivity and progression in TGCTs $[95,97,116]$.

Anecdotally we have observed during development of cisplatin resistant clones of TGCT derived EC cells that some cisplatin resistant clones have a change in morphology (in other words partially differentiated). However, a number of cisplatin resistant cells retain normal morphology. We have found that some of these later clones have a partial decrease in tumorigenicity while others maintain parental tumorigenicity levels (Spinella, manuscript in preparation). This implies that in certain situations chemosensitivity can be uncoupled from tumorigenicity (or pluripotency) in TGCT cells. It is unclear whether the uncoupling mechanism would be driven by epigenetic or genetic alterations or a combination of both. Finally, the model predicts that the unique epigenetic state of TGCTs affords unique vulnerabilities to epigenetic drugs that could mediate recouping or direct apoptotic cell death (Figure 2). 


\section{Conclusions}

In this review we have tried to make the case that epigenetics are exceptionally key drivers of TGCT biology compared to other more common somatic cancers. The reality is that mechanisms of TGCT initiation, progression, and response to therapy are likely multifactorial and involve an interaction between genetic and epigenetic factors. Still, what we know about TGCT thus far, especially aspect of their epidemiology, origins, low mutational burden, and lack of targeted therapeutics does suggest that these tumors may have a unique dependence on distinct epigenetic programs. Unique dependence may also provide unique vulnerabilities to targeted intervention of epigenetic pathways.

Author Contributions: Conceptualization, R.S., Z.F., S.J.F. and M.J.S.; writing-original draft preparation, R.S., Z.F. and M.J.S.; writing—review and editing, R.S., Z.F., S.J.F. and M.J.S.; funding acquisition, M.J.S. All authors have read and agreed to the published version of the manuscript.

Funding: This work was supported by NIH and National Cancer Institute grant R01CA211875 (M.J.S.) and R03CA223709 (M.J.S.) and a Reach Grant from the Alex's Lemonade Stand Foundation (M.J.S.).

Institutional Review Board Statement: Not applicable.

Informed Consent Statement: Not applicable.

Data Availability Statement: Not applicable.

Conflicts of Interest: The authors confirm no conflict of interest.

\section{References}

1. Batool, A.; Karimi, N.; Wu, X.N.; Chen, S.R.; Liu, Y.X. Testicular germ cell tumor: A comprehensive review. Cell. Mol. Life Sci. 2019, 76, 1713-1727. [CrossRef]

2. Lobo, J.; Gillis, A.J.M.; Jerónimo, C.; Henrique, R.; Looijenga, L.H.J. Human germ cell tumors are developmental cancers: Impact of epigenetics on pathobiology and clinic. Int. J. Mol. Sci. 2019, 20, 258. [CrossRef] [PubMed]

3. Williamson, S.R.; Delahunt, B.; Magi-Galluzzi, C.; Algaba, F.; Egevad, L.; Ulbright, T.M.; Tickoo, S.K.; Srigley, J.R.; Epstein, J.I.; Berney, D.M. The World Health Organization 2016 classification of testicular germ cell tumours: A review and update from the International Society of Urological Pathology Testis Consultation Panel. Histopathology 2017, 70, 335-346. [CrossRef] [PubMed]

4. Berney, D.M.; Looijenga, L.H.; Idrees, M.; Oosterhuis, J.W.; Rajpert-De Meyts, E.; Ulbright, T.M.; Skakkebaek, N.E. Germ cell neoplasia in situ (GCNIS): Evolution of the current nomenclature for testicular pre-invasive germ cell malignancy. Histopathology 2016, 69, 7-10. [CrossRef]

5. Oosterhuis, J.W.; Looijenga, L.H. Testicular germ-cell tumours in a broader perspective. Nat. Rev. Cancer 2005, 5, $210-222$. [CrossRef] [PubMed]

6. Bray, F.; Ferlay, J.; Soerjomataram, I.; Siegel, R.L.; Torre, L.A.; Jemal, A. Global cancer statistics 2018: GLOBOCAN estimates of incidence and mortality worldwide for 36 cancers in 185 countries. CA Cancer J. Clin. 2018, 68, 394-424. [CrossRef] [PubMed]

7. Woldu, S.L.; Bagrodia, A. Update on epidemiologic considerations and treatment trends in testicular cancer. Curr. Opin. Urol. 2018, 28, 440-447. [CrossRef]

8. Cai, Q.; Chen, Y.; Zhang, D.; Pan, J.; Xie, Z.; Xu, C.; Li, S.; Zhang, X.; Gao, Y.; Hou, J.; et al. Estimates of over-time trends in incidence and mortality of testicular cancer from 1990 to 2030. Transl. Androl. Urol. 2020, 9, 182-195. [CrossRef]

9. Xing, J.S.; Bai, Z.M. Is testicular dysgenesis syndrome a genetic, endocrine, or environmental disease, or an unexplained reproductive disorder? Life Sci. 2018, 194, 120-129. [CrossRef] [PubMed]

10. Adra, N.; Einhorn, L.H. Testicular cancer update. Clin. Adv. Hematol. Oncol. 2017, 15, 386-396. [PubMed]

11. Saju, S.V.; Radhakrishnan, V.; Ganesan, T.S.; Dhanushkodi, M.; Raja, A.; Selvaluxmy, G.; Sagar, T.G. Factors that impact the outcomes in testicular germ cell tumors in low-middle-income countries. Med. Oncol. 2019, 36, 28. [CrossRef]

12. Giuliano, C.J.; Freemantle, S.J.; Spinella, M.J. Testicular germ cell tumors: A paradigm for the successful treatment of solid tumor stem cells. Curr. Cancer Ther. Rev. 2006, 2, 255-270. [CrossRef]

13. Alsdorf, W.; Seidel, C.; Bokemeyer, C.; Oing, C. Current pharmacotherapy for testicular germ cell cancer. Expert Opin. Pharmacother. 2019, 20, 837-850. [CrossRef] [PubMed]

14. Feldman, D.R.; Patil, S.; Trinos, M.J.; Carousso, M.; Ginsberg, M.S.; Sheinfeld, J.; Bajorin, D.F.; Bosl, G.J.; Motzer, R.J. Progressionfree and overall survival in patients with relapsed/refractory germ cell tumors treated with single-agent chemotherapy: Endpoints for clinical trial design. Cancer 2012, 118, 981-986. [CrossRef]

15. Porcu, P.; Bhatia, S.; Sharma, M.; Einhorn, L.H. Results of treatment after relapse from high-dose chemotherapy in germ cell tumors. J. Clin. Oncol. 2000, 18, 1181-1186. [CrossRef] [PubMed]

16. Fung, C.; Dinh, P., Jr.; Ardeshir-Rouhani-Fard, S.; Schaffer, K.; Fossa, S.D.; Travis, L.B. Toxicities associated with cisplatin-based chemotherapy and radiotherapy in long-term testicular cancer survivors. Adv. Urol. 2018, 2018, 8671832. [CrossRef] 
17. Christensen, J.F.; Bandak, M.; Campbell, A.; Jones, L.W.; Højman, P. Treatment-related cardiovascular late effects and exercise training countermeasures in testicular germ cell cancer survivorship. Acta Oncol. 2015, 54, 592-599. [CrossRef]

18. Curreri, S.A.; Fung, C.; Beard, C.J. Secondary malignant neoplasms in testicular cancer survivors. Urol. Oncol. 2015, 33, 392-398. [CrossRef]

19. Fung, C.; Sesso, H.D.; Williams, A.M.; Kerns, S.L.; Monahan, P.; Abu Zaid, M.; Feldman, D.R.; Hamilton, R.J.; Vaughn, D.J.; Beard, C.J.; et al. Multi-institutional assessment of adverse health outcomes among north american testicular cancer survivors after modern cisplatin-based chemotherapy. J. Clin. Oncol. 2017, 35, 1211-1222. [CrossRef] [PubMed]

20. Oosterhuis, J.W.; Looijenga, L.H.J. Human germ cell tumours from a developmental perspective. Nat. Rev. Cancer 2019, 19, 522-537. [CrossRef] [PubMed]

21. Singla, N.; Lafin, J.T.; Ghandour, R.A.; Kaffenberger, S.; Amatruda, J.F.; Bagrodia, A. Genetics of testicular germ cell tumors. Curr. Opin. Urol. 2019, 29, 344-349. [CrossRef] [PubMed]

22. Elzinga-Tinke, J.E.; Dohle, G.R.; Looijenga, L.H. Etiology and early pathogenesis of malignant testicular germ cell tumors: Towards possibilities for preinvasive diagnosis. Asian J. Androl. 2015, 17, 381-393. [CrossRef] [PubMed]

23. Baroni, T.; Arato, I.; Mancuso, F.; Calafiore, R.; Luca, G. On the origin of testicular germ cell tumors: From gonocytes to testicular cancer. Front. Endocrinol. 2019, 10, 343. [CrossRef]

24. Litchfield, K.; Summersgill, B.; Yost, S.; Sultana, R.; Labreche, K.; Dudakia, D.; Renwick, A.; Seal, S.; Al-Saadi, R.; Broderick, P.; et al. Whole-exome sequencing reveals the mutational spectrum of testicular germ cell tumours. Nat. Commun. 2015, 6, 5973. [CrossRef] [PubMed]

25. Shen, H.; Shih, J.; Hollern, D.P.; Wang, L.; Bowlby, R.; Tickoo, S.K.; Thorsson, V.; Mungall, A.J.; Newton, Y.; Hegde, A.M.; et al. Integrated molecular characterization of testicular germ cell tumors. Cell Rep. 2018, 23, 3392-3406. [CrossRef]

26. Boccellino, M.; Vanacore, D.; Zappavigna, S.; Cavaliere, C.; Rossetti, S.; D’Aniello, C.; Chieffi, P.; Amler, E.; Buonerba, C.; Di Lorenzo, G.; et al. Testicular cancer from diagnosis to epigenetic factors. Oncotarget 2017, 8, 104654-104663. [CrossRef]

27. Ilijazi, D.; Shariat, S.F.; Hassler, M.R.; Lemberger, U.; Ertl, I.E. Epigenetic alterations of testicular germ cell tumours. Curr. Opin. Urol. 2020, 30, 264-270. [CrossRef]

28. Buljubašić, R.; Buljubašić, M.; Bojanac, A.K.; Ulamec, M.; Vlahović, M.; Ježek, D.; Bulić-Jakuš, F.; Sinčić, N. Epigenetics and testicular germ cell tumors. Gene 2018, 661, 22-33. [CrossRef]

29. Singh, R.; Fazal, Z.; Freemantle, S.J.; Spinella, M.J. Mechanisms of cisplatin sensitivity and resistance in testicular germ cell tumors. Cancer Drug Resist. 2019, 2, 580-594. [CrossRef]

30. Oing, C.; Skowron, M.A.; Bokemeyer, C.; Nettersheim, D. Epigenetic treatment combinations to effectively target cisplatin-resistant germ cell tumors: Past, present, and future considerations. Andrology 2019, 7, 487-497. [CrossRef] [PubMed]

31. Cardoso, A.R.; Lobo, J.; Miranda-Gonçalves, V.; Henrique, R.; Jerónimo, C. Epigenetic alterations as therapeutic targets in Testicular Germ Cell Tumours: Current and future application of 'epidrugs'. Epigenetics 2020, 1-20. [CrossRef]

32. Jostes, S.; Nettersheim, D.; Schorle, H. Epigenetic drugs and their molecular targets in testicular germ cell tumours. Nat. Rev. Urol. 2019, 16, 245-259. [CrossRef]

33. Kratz, C.P.; Mai, P.L.; Greene, M.H. Familial testicular germ cell tumours. Best Pract. Res. Clin. Endocrinol. Metab. 2010, 24, 503-513. [CrossRef]

34. Kanetsky, P.A.; Mitra, N.; Vardhanabhuti, S.; Li, M.; Vaughn, D.J.; Letrero, R.; Ciosek, S.L.; Doody, D.R.; Smith, L.M.; Weaver, J.; et al. Common variation in KITLG and at 5 q31.3 predisposes to testicular germ cell cancer. Nat. Genet. 2009, 41, 811-815. [CrossRef]

35. Rapley, E.A.; Turnbull, C.; Al Olama, A.A.; Dermitzakis, E.T.; Linger, R.; Huddart, R.A.; Renwick, A.; Hughes, D.; Hines, S.; Seal, S.; et al. A genome-wide association study of testicular germ cell tumor. Nat. Genet. 2009, 41, 807-810. [CrossRef]

36. Turnbull, C.; Rapley, E.A.; Seal, S.; Pernet, D.; Renwick, A.; Hughes, D.; Ricketts, M.; Linger, R.; Nsengimana, J.; Deloukas, P.; et al Variants near DMRT1, TERT and ATF7IP are associated with testicular germ cell cancer. Nat. Genet. 2010, 42, 604-607. [CrossRef]

37. Kanetsky, P.A.; Mitra, N.; Vardhanabhuti, S.; Vaughn, D.J.; Li, M.; Ciosek, S.L.; Letrero, R.; D'Andrea, K.; Vaddi, M.; Doody, D.R.; et al. A second independent locus within DMRT1 is associated with testicular germ cell tumor susceptibility. Hum. Mol. Genet. 2011, 20, 3109-3117. [CrossRef]

38. Chung, C.C.; Kanetsky, P.A.; Wang, Z.; Hildebrandt, M.A.; Koster, R.; Skotheim, R.I.; Kratz, C.P.; Turnbull, C.; Cortessis, V.K.; Bakken, A.C.; et al. Meta-analysis identifies four new loci associated with testicular germ cell tumor. Nat. Genet. 2013, 45, 680-685. [CrossRef] [PubMed]

39. Ruark, E.; Seal, S.; McDonald, H.; Zhang, F.; Elliot, A.; Lau, K.; Perdeaux, E.; Rapley, E.; Eeles, R.; Peto, J.; et al. Identification of nine new susceptibility loci for testicular cancer, including variants near DAZL and PRDM14. Nat. Genet. 2013, 45, 686-689. [CrossRef]

40. Schumacher, F.R.; Wang, Z.; Skotheim, R.I.; Koster, R.; Chung, C.C.; Hildebrandt, M.A.; Kratz, C.P.; Bakken, A.C.; Bishop, D.T.; Cook, M.B.; et al. Testicular germ cell tumor susceptibility associated with the UCK2 locus on chromosome 1q23. Hum. Mol. Genet. 2013, 22, 2748-2753. [CrossRef]

41. Litchfield, K.; Holroyd, A.; Lloyd, A.; Broderick, P.; Nsengimana, J.; Eeles, R.; Easton, D.F.; Dudakia, D.; Bishop, D.T.; Reid, A.; et al. Identification of four new susceptibility loci for testicular germ cell tumour. Nat. Commun. 2015, 6, 8690. [CrossRef] 
42. Litchfield, K.; Sultana, R.; Renwick, A.; Dudakia, D.; Seal, S.; Ramsay, E.; Powell, S.; Elliott, A.; Warren-Perry, M.; Eeles, R.; et al. Multi-stage genome-wide association study identifies new susceptibility locus for testicular germ cell tumour on chromosome 3q25. Hum. Mol. Genet. 2015, 24, 1169-1176. [CrossRef]

43. Wang, Z.; McGlynn, K.A.; Rajpert-De Meyts, E.; Bishop, D.T.; Chung, C.C.; Dalgaard, M.D.; Greene, M.H.; Gupta, R.; Grotmol, T.; Haugen, T.B.; et al. Meta-analysis of five genome-wide association studies identifies multiple new loci associated with testicular germ cell tumor. Nat. Genet. 2017, 49, 1141-1147. [CrossRef] [PubMed]

44. Litchfield, K.; Loveday, C.; Levy, M.; Dudakia, D.; Rapley, E.; Nsengimana, J.; Bishop, D.T.; Reid, A.; Huddart, R.; Broderick, P.; et al. Large-scale sequencing of testicular germ cell tumour (tgct) cases excludes major TGCT predisposition gene. Eur. Urol. 2018, 73, 828-831. [CrossRef] [PubMed]

45. Loveday, C.; Law, P.; Litchfield, K.; Levy, M.; Holroyd, A.; Broderick, P.; Kote-Jarai, Z.; Dunning, A.M.; Muir, K.; Peto, J.; et al. Large-scale analysis demonstrates familial testicular cancer to have polygenic aetiology. Eur. Urol. 2018, 74, 248-252. [CrossRef]

46. Dieckmann, K.P.; Rube, C.; Henke, R.P. Association of Down's syndrome and testicular cancer. J. Urol. 1997, 157, 1701-1704. [CrossRef]

47. Moller, H.; Skakkebaek, N.E. Risk of testicular cancer in subfertile men: Case-control study. BMJ 1999, 318, 559-562. [CrossRef] [PubMed]

48. Jacobsen, R.; Bostofte, E.; Engholm, G.; Hansen, J.; Olsen, J.H.; Skakkebaek, N.E.; Moller, H. Risk of testicular cancer in men with abnormal semen characteristics: Cohort study. BMJ 2000, 321, 789-792. [CrossRef]

49. Fossa, S.D.; Chen, J.; Schonfeld, S.J.; McGlynn, K.A.; McMaster, M.L.; Gail, M.H.; Travis, L.B. Risk of contralateral testicular cancer: A population-based study of 29,515 U.S. men. J. Natl. Cancer Inst. 2005, 97, 1056-1066. [CrossRef]

50. Cook, M.B.; Akre, O.; Forman, D.; Madigan, M.P.; Richiardi, L.; McGlynn, K.A. A systematic review and meta-analysis of perinatal variables in relation to the risk of testicular cancer-Experiences of the mother. Int. J. Epidemiol. 2009, 38, 1532-1542. [CrossRef]

51. Cook, M.B.; Akre, O.; Forman, D.; Madigan, M.P.; Richiardi, L.; McGlynn, K.A. A systematic review and meta-analysis of perinatal variables in relation to the risk of testicular cancer-Experiences of the son. Int. J. Epidemiol. 2010, 39, 1605-1618. [CrossRef] [PubMed]

52. Maule, M.; Malavassi, J.L.; Richiardi, L. Age at puberty and risk of testicular cancer: A meta-analysis. Int. J. Androl. 2012, 35, 828-834. [CrossRef]

53. Trabert, B.; Zugna, D.; Richiardi, L.; McGlynn, K.A.; Akre, O. Congenital malformations and testicular germ cell tumors. Int. J. Cancer 2013, 133, 1900-1904. [CrossRef]

54. Hanson, H.A.; Anderson, R.E.; Aston, K.I.; Carrell, D.T.; Smith, K.R.; Hotaling, J.M. Subfertility increases risk of testicular cancer: Evidence from population-based semen samples. Fertil. Steril. 2016, 105, 322-328.e321. [CrossRef] [PubMed]

55. Skakkebaek, N.E.; Rajpert-De Meyts, E.; Buck Louis, G.M.; Toppari, J.; Andersson, A.M.; Eisenberg, M.L.; Jensen, T.K.; Jørgensen, N.; Swan, S.H.; Sapra, K.J.; et al. Male reproductive disorders and fertility trends: Influences of environment and genetic susceptibility. Physiol. Rev. 2016, 96, 55-97. [CrossRef] [PubMed]

56. Piltoft, J.S.; Larsen, S.B.; Dalton, S.O.; Johansen, C.; Baker, J.L.; Cederkvist, L.; Andersen, I. Early life risk factors for testicular cancer: A case-cohort study based on the Copenhagen School Health Records Register. Acta Oncol. 2017, 56, 220-224. [CrossRef] [PubMed]

57. Skakkebaek, N.E.; Rajpert-De Meyts, E.; Main, K.M. Testicular dysgenesis syndrome: An increasingly common developmental disorder with environmental aspects. Hum. Reprod. 2001, 16, 972-978. [CrossRef]

58. Selvi, I.; Ozturk, E.; Yikilmaz, T.N.; Sarikaya, S.; Basar, H. Effects of testicular dysgenesis syndrome components on testicular germ cell tumor prognosis and oncological outcomes. Int. Braz. J. Urol. 2020, 46, 725-740. [CrossRef]

59. Sharma, A.; Mollier, J.; Brocklesby, R.W.K.; Caves, C.; Jayasena, C.N.; Minhas, S. Endocrine-disrupting chemicals and male reproductive health. Reprod. Med. Biol. 2020, 19, 243-253. [CrossRef] [PubMed]

60. Fénichel, P.; Chevalier, N. Is testicular germ cell cancer estrogen dependent? The Role of Endocrine Disrupting Chemicals. Endocrinology 2019, 160, 2981-2989. [CrossRef]

61. Bhartiya, D.; Kaushik, A. Testicular stem cell dysfunction due to environmental insults could be responsible for deteriorating reproductive health of men. Reprod. Sci. 2021, 28, 649-658. [CrossRef] [PubMed]

62. Hersmus, R.; van Bever, Y.; Wolffenbuttel, K.P.; Biermann, K.; Cools, M.; Looijenga, L.H. The biology of germ cell tumors in disorders of sex development. Clin. Genet. 2017, 91, 292-301. [CrossRef] [PubMed]

63. Looijenga, L.H.J.; Kao, C.S.; Idrees, M.T. Predicting gonadal germ cell cancer in people with disorders of sex development; insights from developmental biology. Int. J. Mol. Sci. 2019, 20, 5017. [CrossRef]

64. Looijenga, L.H.; Van Agthoven, T.; Biermann, K. Development of malignant germ cells-the genvironmental hypothesis. Int. J. Dev. Biol. 2013, 57, 241-253. [CrossRef] [PubMed]

65. Rajpert-De Meyts, E.; Skakkebaek, N.E.; Toppari, J. Testicular Cancer Pathogenesis, Diagnosis and Endocrine Aspects. In Endotext; Feingold, K.R., Anawalt, B., Boyce, A., Chrousos, G., de Herder, W.W., Dungan, K., Grossman, A., Hershman, J.M., Hofland, J., Kaltsas, G., et al., Eds.; MDText.com, Inc.: South Dartmouth, MA, USA, 2018.

66. Nicholls, P.K.; Schorle, H.; Naqvi, S.; Hu, Y.C.; Fan, Y.; Carmell, M.A.; Dobrinski, I.; Watson, A.L.; Carlson, D.F.; Fahrenkrug, S.C.; et al. Mammalian germ cells are determined after PGC colonization of the nascent gonad. Proc. Natl. Acad. Sci. USA 2019, 116, 25677-25687. [CrossRef] 
67. Rajpert-De Meyts, E. Developmental model for the pathogenesis of testicular carcinoma in situ: Genetic and environmental aspects. Hum. Reprod. Update 2006, 12, 303-323. [CrossRef] [PubMed]

68. Rajpert-De Meyts, E.; Nielsen, J.E.; Skakkebaek, N.E.; Almstrup, K. Diagnostic markers for germ cell neoplasms: From placentallike alkaline phosphatase to micro-RNAs. Folia Histochem. Cytobiol. 2015, 53, 177-188. [CrossRef] [PubMed]

69. Lafin, J.T.; Bagrodia, A.; Woldu, S.; Amatruda, J.F. New insights into germ cell tumor genomics. Andrology 2019, 7, 507-515. [CrossRef]

70. Baker, D.E.; Harrison, N.J.; Maltby, E.; Smith, K.; Moore, H.D.; Shaw, P.J.; Heath, P.R.; Holden, H.; Andrews, P.W. Adaptation to culture of human embryonic stem cells and oncogenesis in vivo. Nat. Biotechnol. 2007, 25, 207-215. [CrossRef]

71. Loveday, C.; Litchfield, K.; Proszek, P.Z.; Cornish, A.J.; Santo, F.; Levy, M.; Macintyre, G.; Holryod, A.; Broderick, P.; Dudakia, D.; et al. Genomic landscape of platinum resistant and sensitive testicular cancers. Nat. Commun. 2020, 11, 2189. [CrossRef]

72. Pathak, A.; Stewart, D.R.; Faucz, F.R.; Xekouki, P.; Bass, S.; Vogt, A.; Zhang, X.; Boland, J.; Yeager, M.; Loud, J.T.; et al. Rare inactivating PDE11A variants associated with testicular germ cell tumors. Endocr. Relat. Cancer 2015, 22, 909-917. [CrossRef] [PubMed]

73. Dorssers, L.C.J.; Gillis, A.J.M.; Stoop, H.; van Marion, R.; Nieboer, M.M.; van Riet, J.; van de Werken, H.J.G.; Oosterhuis, J.W.; de Ridder, J.; Looijenga, L.H.J. Molecular heterogeneity and early metastatic clone selection in testicular germ cell cancer development. Br. J. Cancer 2019, 120, 444-452. [CrossRef]

74. McGlynn, K.A.; Trabert, B. Adolescent and adult risk factors for testicular cancer. Nat. Rev. Urol. 2012, 9, 339-349. [CrossRef]

75. Soteriades, E.S.; Kim, J.; Christophi, C.A.; Kales, S.N. Cancer incidence and mortality in firefighters: A state-of-the-art review and meta-analysis. Asian Pac. J. Cancer Prev. 2019, 20, 3221-3231. [CrossRef]

76. Romerius, P.; Giwercman, A.; Moell, C.; Relander, T.; Cavallin-Stahl, E.; Wiebe, T.; Hallden, C.; Giwercman, Y.L. Estrogen receptor alpha single nucleotide polymorphism modifies the risk of azoospermia in childhood cancer survivors. Pharm. Genom. 2011, 21, 263-269. [CrossRef]

77. Richiardi, L.; Bellocco, R.; Adami, H.O.; Torrang, A.; Barlow, L.; Hakulinen, T.; Rahu, M.; Stengrevics, A.; Storm, H.; Tretli, S.; et al. Testicular cancer incidence in eight northern European countries: Secular and recent trends. Cancer Epidemiol. Biomark. Prev. 2004, 13, 2157-2166.

78. Figueroa, J.D.; Sakoda, L.C.; Graubard, B.I.; Chanock, S.; Rubertone, M.V.; Erickson, R.L.; McGlynn, K.A. Genetic variation in hormone metabolizing genes and risk of testicular germ cell tumors. Cancer Causes Control 2008, 19, 917-929. [CrossRef]

79. Kristiansen, W.; Haugen, T.B.; Witczak, O.; Andersen, J.M.; Fossa, S.D.; Aschim, E.L. CYP1A1, CYP3A5 and CYP3A7 polymorphisms and testicular cancer susceptibility. Int. J. Androl. 2011, 34, 77-83. [CrossRef] [PubMed]

80. Lobo, J.; Jerónimo, C.; Henrique, R. Cisplatin resistance in testicular germ cell tumors: Current challenges from various perspectives. Cancers 2020, 12, 1601. [CrossRef] [PubMed]

81. Schmidtova, S.; Kalavska, K.; Kucerova, L. Molecular mechanisms of cisplatin chemoresistance and its circumventing in testicular germ cell tumors. Curr. Oncol. Rep. 2018, 20, 88. [CrossRef] [PubMed]

82. Kalavska, K.; Conteduca, V.; De Giorgi, U.; Mego, M. Molecular mechanisms of resistance in testicular germ cell tumors-clinical implications. Curr. Cancer Drug Targets 2018, 18, 967-978. [CrossRef]

83. Barrett, M.T.; Lenkiewicz, E.; Malasi, S.; Stanton, M.; Slack, J.; Andrews, P.; Pagliaro, L.; Bryce, A.H. Clonal analyses of refractory testicular germ cell tumors. PLoS ONE 2019, 14, e213815. [CrossRef]

84. Taylor-Weiner, A.; Zack, T.; O’Donnell, E.; Guerriero, J.L.; Bernard, B.; Reddy, A.; Han, G.C.; AlDubayan, S.; Amin-Mansour, A.; Schumacher, S.E.; et al. Genomic evolution and chemoresistance in germ-cell tumours. Nature 2016, 540, 114-118. [CrossRef]

85. Bilen, M.A.; Hess, K.R.; Campbell, M.T.; Wang, J.; Broaddus, R.R.; Karam, J.A.; Ward, J.F.; Wood, C.G.; Choi, S.L.; Rao, P.; et al. Intratumoral heterogeneity and chemoresistance in nonseminomatous germ cell tumor of the testis. Oncotarget 2016, 7, 86280-86289. [CrossRef]

86. Bagrodia, A.; Lee, B.H.; Lee, W.; Cha, E.K.; Sfakianos, J.P.; Iyer, G.; Pietzak, E.J.; Gao, S.P.; Zabor, E.C.; Ostrovnaya, I.; et al. Genetic determinants of cisplatin resistance in patients with advanced germ cell tumors. J. Clin. Oncol. 2016, 34, 4000-4007. [CrossRef]

87. Bloom, J.C.; Loehr, A.R.; Schimenti, J.C.; Weiss, R.S. Germline genome protection: Implications for gamete quality and germ cell tumorigenesis. Andrology 2019, 7, 516-526. [CrossRef]

88. Cierna, Z.; Miskovska, V.; Roska, J.; Jurkovicova, D.; Pulzova, L.B.; Sestakova, Z.; Hurbanova, L.; Machalekova, K.; Chovanec, M.; Rejlekova, K.; et al. Increased levels of XPA might be the basis of cisplatin resistance in germ cell tumours. BMC Cancer 2020, 20, 17. [CrossRef] [PubMed]

89. Awuah, S.G.; Riddell, I.A.; Lippard, S.J. Repair shielding of platinum-DNA lesions in testicular germ cell tumors by high-mobility group box protein 4 imparts cisplatin hypersensitivity. Proc. Natl. Acad. Sci. USA 2017, 114, 950-955. [CrossRef]

90. Mendoza, J.; Martínez, J.; Hernández, C.; Pérez-Montiel, D.; Castro, C.; Fabián-Morales, E.; Santibáñez, M.; González-Barrios, R.; Díaz-Chávez, J.; Andonegui, M.A.; et al. Association between ERCC1 and XPA expression and polymorphisms and the response to cisplatin in testicular germ cell tumours. Br. J. Cancer 2013, 109, 68-75. [CrossRef] [PubMed]

91. Usanova, S.; Piée-Staffa, A.; Sied, U.; Thomale, J.; Schneider, A.; Kaina, B.; Köberle, B. Cisplatin sensitivity of testis tumour cells is due to deficiency in interstrand-crosslink repair and low ERCC1-XPF expression. Mol. Cancer 2010, 9, 248. [CrossRef] [PubMed]

92. Honecker, F.; Wermann, H.; Mayer, F.; Gillis, A.J.; Stoop, H.; van Gurp, R.J.; Oechsle, K.; Steyerberg, E.; Hartmann, J.T.; Dinjens, W.N.; et al. Microsatellite instability, mismatch repair deficiency, and BRAF mutation in treatment-resistant germ cell tumors. J. Clin. Oncol. 2009, 27, 2129-2136. [CrossRef] 
93. Caggiano, C.; Cavallo, F.; Giannattasio, T.; Cappelletti, G.; Rossi, P.; Grimaldi, P.; Feldman, D.R.; Jasin, M.; Barchi, M. Testicular germ cell tumors acquire cisplatin resistance by rebalancing the usage of DNA repair pathways. Cancers 2021, 13, 787. [CrossRef]

94. Sakurai, Y.; Ichinoe, M.; Yoshida, K.; Nakazato, Y.; Saito, S.; Satoh, M.; Nakada, N.; Sanoyama, I.; Umezawa, A.; Numata, Y.; et al. Inactivation of REV7 enhances chemosensitivity and overcomes acquired chemoresistance in testicular germ cell tumors. Cancer Lett. 2020, 489, 100-110. [CrossRef]

95. Lobo, J.; Constâncio, V.; Guimarães-Teixeira, C.; Leite-Silva, P.; Miranda-Gonçalves, V.; Sequeira, J.P.; Pistoni, L.; Guimarães, R.; Cantante, M.; Braga, I.; et al. Promoter methylation of DNA homologous recombination genes is predictive of the responsiveness to PARP inhibitor treatment in testicular germ cell tumors. Mol. Oncol. 2021. [CrossRef]

96. Cavallo, F.; Graziani, G.; Antinozzi, C.; Feldman, D.R.; Houldsworth, J.; Bosl, G.J.; Chaganti, R.S.; Moynahan, M.E.; Jasin, M.; Barchi, M. Reduced proficiency in homologous recombination underlies the high sensitivity of embryonal carcinoma testicular germ cell tumors to cisplatin and poly (adp-ribose) polymerase inhibition. PLoS ONE 2012, 7, e51563. [CrossRef] [PubMed]

97. Olasz, J.; Mándoky, L.; Géczi, L.; Bodrogi, I.; Csuka, O.; Bak, M. Influence of hMLH1 methylation, mismatch repair deficiency and microsatellite instability on chemoresistance of testicular germ-cell tumors. Anticancer Res. 2005, 25, 4319-4324. [PubMed]

98. Kurimoto, K.; Saitou, M. Epigenome regulation during germ cell specification and development from pluripotent stem cells. Curr. Opin. Genet. Dev. 2018, 52, 57-64. [CrossRef]

99. Gainetdinov, I.V.; Skvortsova, Y.V.; Kondratieva, S.A.; Klimov, A.; Tryakin, A.A.; Azhikina, T.L. Assessment of piRNA biogenesis and function in testicular germ cell tumors and their precursor germ cell neoplasia in situ. BMC Cancer 2018, 18, 20. [CrossRef] [PubMed]

100. Ferreira, H.J.; Heyn, H.; Garcia del Muro, X.; Vidal, A.; Larriba, S.; Muñoz, C.; Villanueva, A.; Esteller, M. Epigenetic loss of the PIWI/piRNA machinery in human testicular tumorigenesis. Epigenetics 2014, 9, 113-118. [CrossRef]

101. Killian, J.K.; Dorssers, L.C.; Trabert, B.; Gillis, A.J.; Cook, M.B.; Wang, Y.; Waterfall, J.J.; Stevenson, H.; Smith, W.I., Jr.; Noyes, $\mathrm{N}$; ; et al. Imprints and DPPA3 are bypassed during pluripotency- and differentiation-coupled methylation reprogramming in testicular germ cell tumors. Genome Res. 2016, 26, 1490-1504. [CrossRef]

102. Rijlaarsdam, M.A.; Tax, D.M.; Gillis, A.J.; Dorssers, L.C.; Koestler, D.C.; de Ridder, J.; Looijenga, L.H. Genome wide DNA methylation profiles provide clues to the origin and pathogenesis of germ cell tumors. PLoS ONE 2015, 10, e0122146. [CrossRef]

103. Ghodoussipour, S.; Daneshmand, S. Postchemotherapy resection of residual mass in nonseminomatous germ cell tumor. Urol. Clin. N. Am. 2019, 46, 389-398. [CrossRef]

104. Pierpont, T.M.; Lyndaker, A.M.; Anderson, C.M.; Jin, Q.; Moore, E.S.; Roden, J.L.; Braxton, A.; Bagepalli, L.; Kataria, N.; Hu, H.Z.; et al. Chemotherapy-induced depletion of oct4-positive cancer stem cells in a mouse model of malignant testicular cancer. Cell Rep. 2017, 21, 1896-1909. [CrossRef]

105. Mueller, T.; Mueller, L.P.; Luetzkendorf, J.; Voigt, W.; Simon, H.; Schmoll, H.J. Loss of Oct-3/4 expression in embryonal carcinoma cells is associated with induction of cisplatin resistance. Tumor Biol. 2006, 27, 71-83. [CrossRef] [PubMed]

106. Mueller, T.; Mueller, L.P.; Holzhausen, H.J.; Witthuhn, R.; Albers, P.; Schmoll, H.J. Histological evidence for the existence of germ cell tumor cells showing embryonal carcinoma morphology but lacking OCT4 expression and cisplatin sensitivity. Histochem. Cell. Biol. 2010, 134, 197-204. [CrossRef]

107. Gutekunst, M.; Mueller, T.; Weilbacher, A.; Dengler, M.A.; Bedke, J.; Kruck, S.; Oren, M.; Aulitzky, W.E.; van der Kuip, H. Cisplatin hypersensitivity of testicular germ cell tumors is determined by high constitutive Noxa levels mediated by Oct- 4 . Cancer Res. 2013, 73, 1460-1469. [CrossRef]

108. Koster, R.; di Pietro, A.; Timmer-Bosscha, H.; Gibcus, J.H.; van den Berg, A.; Suurmeijer, A.J.; Bischoff, R.; Gietema, J.A.; de Jong, S. Cytoplasmic p21 expression levels determine cisplatin resistance in human testicular cancer. J. Clin. Investig. 2010, 120, 3594-3605. [CrossRef] [PubMed]

109. Wu, Y.C.; Ling, T.Y.; Lu, S.H.; Kuo, H.C.; Ho, H.N.; Yeh, S.D.; Shen, C.N.; Huang, Y.H. Chemotherapeutic sensitivity of testicular germ cell tumors under hypoxic conditions is negatively regulated by SENP1-controlled sumoylation of OCT4. Cancer Res. 2012, 72, 4963-4973. [CrossRef]

110. Gutekunst, M.; Oren, M.; Weilbacher, A.; Dengler, M.A.; Markwardt, C.; Thomale, J.; Aulitzky, W.E.; van der Kuip, H. p53 hypersensitivity is the predominant mechanism of the unique responsiveness of testicular germ cell tumor (TGCT) cells to cisplatin. PLoS ONE 2011, 6, e19198. [CrossRef] [PubMed]

111. Nettersheim, D.; Heimsoeth, A.; Jostes, S.; Schneider, S.; Fellermeyer, M.; Hofmann, A.; Schorle, H. SOX2 is essential for in vivo reprogramming of seminoma-like TCam-2 cells to an embryonal carcinoma-like fate. Oncotarget 2016, 7, 47095-47110. [CrossRef]

112. Abad, E.; Graifer, D.; Lyakhovich, A. DNA damage response and resistance of cancer stem cells. Cancer Lett. 2020, 474, 106-117. [CrossRef] [PubMed]

113. Fazal, Z.; Singh, R.; Fang, F.; Bikorimana, E.; Baldwin, H.; Corbet, A.; Tomlin, M.; Yerby, C.; Adra, N.; Albany, C.; et al. Hypermethylation and global remodelling of DNA methylation is associated with acquired cisplatin resistance in testicular germ cell tumours. Epigenetics 2020, 1-14. [CrossRef]

114. Koul, S.; McKiernan, J.M.; Narayan, G.; Houldsworth, J.; Bacik, J.; Dobrzynski, D.L.; Assaad, A.M.; Mansukhani, M.; Reuter, V.E.; Bosl, G.J.; et al. Role of promoter hypermethylation in Cisplatin treatment response of male germ cell tumors. Mol. Cancer 2004, 3, 16. [CrossRef] 
115. Wermann, H.; Stoop, H.; Gillis, A.J.; Honecker, F.; van Gurp, R.J.; Ammerpohl, O.; Richter, J.; Oosterhuis, J.W.; Bokemeyer, C.; Looijenga, L.H. Global DNA methylation in fetal human germ cells and germ cell tumours: Association with differentiation and cisplatin resistance. J. Pathol. 2010, 221, 433-442. [CrossRef]

116. Martinelli, C.; Lengert, A.V.H.; Cárcano, F.M.; Silva, E.C.A.; Brait, M.; Lopes, L.F.; Vidal, D.O. MGMT and CALCA promoter methylation are associated with poor prognosis in testicular germ cell tumor patients. Oncotarget 2017, 8, 50608-50617. [CrossRef] [PubMed]

117. Lobo, J.; Nunes, S.P.; Gillis, A.J.M.; Barros-Silva, D.; Miranda-Gonçalves, V.; Berg, A.V.D.; Cantante, M.; Guimarães, R.; Henrique, R.; Jerónimo, C.; et al. XIST-promoter demethylation as tissue biomarker for testicular germ cell tumors and spermatogenesis quality. Cancers 2019, 11, 1385. [CrossRef]

118. Bo, H.; Cao, K.; Tang, R.; Zhang, H.; Gong, Z.; Liu, Z.; Liu, J.; Li, J.; Fan, L. A network-based approach to identify DNA methylation and its involved molecular pathways in testicular germ cell tumors. J. Cancer 2019, 10, 893-902. [CrossRef] [PubMed]

119. Lobo, J.; Guimarães, R.; Miranda-Gonçalves, V.; Monteiro-Reis, S.; Cantante, M.; Antunes, L.; Braga, I.; Maurício, J.; Looijenga, L.H.; Jerónimo, C.; et al. Differential expression of DNA methyltransferases and demethylases among the various testicular germ cell tumor subtypes. Epigenomics 2020, 12, 1579-1592. [CrossRef]

120. Lobo, J.; Henrique, R.; Jerónimo, C. The role of DNA/histone modifying enzymes and chromatin remodeling complexes in testicular germ cell tumors. Cancers 2018, 11, 6. [CrossRef]

121. Albany, C.; Hever-Jardine, M.P.; von Herrmann, K.M.; Yim, C.Y.; Tam, J.; Warzecha, J.M.; Shin, L.; Bock, S.E.; Curran, B.S.; Chaudhry, A.S.; et al. Refractory testicular germ cell tumors are highly sensitive to the second generation DNA methylation inhibitor guadecitabine. Oncotarget 2017, 8, 2949-2959. [CrossRef]

122. Biswal, B.K.; Beyrouthy, M.J.; Hever-Jardine, M.P.; Armstrong, D.; Tomlinson, C.R.; Christensen, B.C.; Marsit, C.J.; Spinella, M.J. Acute hypersensitivity of pluripotent testicular cancer-derived embryonal carcinoma to low-dose 5-aza deoxycytidine is associated with global DNA Damage-associated p53 activation, anti-pluripotency and DNA demethylation. PLoS ONE 2012, 7, e53003. [CrossRef] [PubMed]

123. Beyrouthy, M.J.; Garner, K.M.; Hever, M.P.; Freemantle, S.J.; Eastman, A.; Dmitrovsky, E.; Spinella, M.J. High DNA methyltransferase 3B expression mediates 5-aza-deoxycytidine hypersensitivity in testicular germ cell tumors. Cancer Res. 2009, 69, 9360-9366. [CrossRef]

124. Oing, C.; Verem, I.; Mansour, W.Y.; Bokemeyer, C.; Dyshlovoy, S.; Honecker, F. 5-Azacitidine exerts prolonged pro-apoptotic effects and overcomes cisplatin-resistance in non-seminomatous germ cell tumor cells. Int. J. Mol. Sci. 2018, 20, 21. [CrossRef] [PubMed]

125. Wongtrakoongate, P.; Li, J.; Andrews, P.W. Aza-deoxycytidine induces apoptosis or differentiation via DNMT3B and targets embryonal carcinoma cells but not their differentiated derivatives. Br. J. Cancer 2014, 110, 2131-2138. [CrossRef]

126. Lobo, J.; Cardoso, A.R.; Miranda-Gonçalves, V.; Looijenga, L.H.J.; Lopez, M.; Arimondo, P.B.; Henrique, R.; Jerónimo, C. Targeting germ cell tumors with the newly synthesized flavanone-derived compound mlo1302 efficiently reduces tumor cell viability and induces apoptosis and cell cycle arrest. Pharmaceutics 2021, 13, 73. [CrossRef]

127. Albany, C.; Fazal, Z.; Singh, R.; Bikorimana, E.; Adra, N.; Hanna, N.H.; Einhorn, L.H.; Perkins, S.M.; Sandusky, G.E.; Christensen, B.C.; et al. A phase 1 study of combined guadecitabine and cisplatin in platinum refractory germ cell cancer. Cancer Med. 2020. [CrossRef]

128. Dhar, S.S.; Lee, S.H.; Chen, K.; Zhu, G.; Oh, W.; Allton, K.; Gafni, O.; Kim, Y.Z.; Tomoiga, A.S.; Barton, M.C.; et al. An essential role for UTX in resolution and activation of bivalent promoters. Nucleic Acids Res. 2016, 44, 3659-3674. [CrossRef]

129. Li, F.; Wan, M.; Zhang, B.; Peng, Y.; Zhou, Y.; Pi, C.; Xu, X.; Ye, L.; Zhou, X.; Zheng, L. Bivalent Histone Modifications and Development. Curr. Stem Cell Res. Ther. 2018, 13, 83-90. [CrossRef] [PubMed]

130. Lobo, J.; Barros-Silva, D.; Henrique, R.; Jerónimo, C. The emerging role of epitranscriptomics in cancer: Focus on urological tumors. Genes 2018, 9, 552. [CrossRef] [PubMed]

131. Lobo, J.; Guimarães-Teixeira, C.; Barros-Silva, D.; Miranda-Gonçalves, V.; Camilo, V.; Guimarães, R.; Cantante, M.; Braga, I.; Maurício, J.; Oing, C.; et al. Efficacy of HDAC inhibitors belinostat and panobinostat against cisplatin-sensitive and cisplatinresistant testicular germ cell tumors. Cancers 2020, 12, 2903. [CrossRef]

132. Wang, D.; Li, W.; Zhao, R.; Chen, L.; Liu, N.; Tian, Y.; Zhao, H.; Xie, M.; Lu, F.; Fang, Q.; et al. Stabilized peptide HDAC inhibitors derived from HDAC1 substrate H3K56 for the treatment of cancer stem-like cells in vivo. Cancer Res. 2019, 79, $1769-1783$. [CrossRef]

133. Steinemann, G.; Dittmer, A.; Kuzyniak, W.; Hoffmann, B.; Schrader, M.; Schobert, R.; Biersack, B.; Nitzsche, B.; Höpfner, M. Animacroxam, a novel dual-mode compound targeting histone deacetylases and cytoskeletal integrity of testicular germ cell cancer cells. Mol. Cancer Ther. 2017, 16, 2364-2374. [CrossRef] [PubMed]

134. Nettersheim, D.; Berger, D.; Jostes, S.; Skowron, M.; Schorle, H. Deciphering the molecular effects of romidepsin on germ cell tumours: DHRS2 is involved in cell cycle arrest but not apoptosis or induction of romidepsin effectors. J. Cell Mol. Med. 2019, 23, 670-679. [CrossRef]

135. Nettersheim, D.; Jostes, S.; Fabry, M.; Honecker, F.; Schumacher, V.; Kirfel, J.; Kristiansen, G.; Schorle, H. A signaling cascade including ARID1A, GADD45B and DUSP1 induces apoptosis and affects the cell cycle of germ cell cancers after romidepsin treatment. Oncotarget 2016, 7, 74931-74946. [CrossRef] 
136. Nettersheim, D.; Gillis, A.; Biermann, K.; Looijenga, L.H.; Schorle, H. The seminoma cell line TCam-2 is sensitive to HDAC inhibitor depsipeptide but tolerates various other chemotherapeutic drugs and loss of NANOG expression. Genes Chromosomes Cancer 2011, 50, 1033-1042. [CrossRef] [PubMed]

137. Wang, J.; Lu, F.; Ren, Q.; Sun, H.; Xu, Z.; Lan, R.; Liu, Y.; Ward, D.; Quan, J.; Ye, T.; et al. Novel histone demethylase LSD1 inhibitors selectively target cancer cells with pluripotent stem cell properties. Cancer Res. 2011, 71, 7238-7249. [CrossRef]

138. Jostes, S.; Nettersheim, D.; Fellermeyer, M.; Schneider, S.; Hafezi, F.; Honecker, F.; Schumacher, V.; Geyer, M.; Kristiansen, G.; Schorle, H. The bromodomain inhibitor JQ1 triggers growth arrest and apoptosis in testicular germ cell tumours in vitro and in vivo. J. Cell Mol. Med. 2017, 21, 1300-1314. [CrossRef]

139. Singh, R.; Fazal, Z.; Corbet, A.K.; Bikorimana, E.; Rodriguez, J.C.; Khan, E.M.; Shahid, K.; Freemantle, S.J.; Spinella, M.J. Epigenetic remodeling through downregulation of polycomb repressive complex 2 mediates chemotherapy resistance in testicular germ cell tumors. Cancers 2019, 11, 796. [CrossRef]

140. Regouc, M.; Belge, G.; Lorch, A.; Dieckmann, K.P.; Pichler, M. Non-Coding microRNAs as Novel Potential Tumor Markers in Testicular Cancer. Cancers 2020, 12, 749. [CrossRef]

141. Nappi, L.; Nichols, C. MicroRNAs as biomarkers for germ cell tumors. Urol. Clin. N. Am. 2019, 46, 449-457. [CrossRef]

142. Radtke, A.; Cremers, J.F.; Kliesch, S.; Riek, S.; Junker, K.; Mohamed, S.A.; Anheuser, P.; Belge, G.; Dieckmann, K.P. Can germ cell neoplasia in situ be diagnosed by measuring serum levels of microRNA371a-3p? J. Cancer Res. Clin. Oncol. 2017, 143, $2383-2392$. [CrossRef]

143. Nappi, L.; Thi, M.; Adra, N.; Hamilton, R.J.; Leao, R.; Lavoie, J.M.; Soleimani, M.; Eigl, B.J.; Chi, K.; Gleave, M.; et al. Integrated expression of circulating mir375 and mir371 to identify teratoma and active germ cell malignancy components in malignant germ cell tumors. Eur. Urol. 2021, 79, 16-19. [CrossRef]

144. Voorhoeve, P.M.; le Sage, C.; Schrier, M.; Gillis, A.J.; Stoop, H.; Nagel, R.; Liu, Y.P.; van Duijse, J.; Drost, J.; Griekspoor, A.; et al. A genetic screen implicates miRNA-372 and miRNA-373 as oncogenes in testicular germ cell tumors. Cell 2006, 124, 1169-1181. [CrossRef] [PubMed]

145. Murray, M.J.; Saini, H.K.; Siegler, C.A.; Hanning, J.E.; Barker, E.M.; van Dongen, S.; Ward, D.M.; Raby, K.L.; Groves, I.J.; Scarpini, C.G.; et al. LIN28 Expression in malignant germ cell tumors downregulates let-7 and increases oncogene levels. Cancer Res. 2013, 73, 4872-4884. [CrossRef]

146. Chen, B.F.; Suen, Y.K.; Gu, S.; Li, L.; Chan, W.Y. A miR-199a/miR-214 self-regulatory network via PSMD10, TP53 and DNMT1 in testicular germ cell tumor. Sci. Rep. 2014, 4, 6413. [CrossRef]

147. Das, M.K.; Evensen, H.S.F.; Furu, K.; Haugen, T.B. miRNA-302s may act as oncogenes in human testicular germ cell tumours. Sci. Rep. 2019, 9, 9189. [CrossRef] [PubMed]

148. Karakaidos, P.; Karagiannis, D.; Rampias, T. Resolving DNA Damage: Epigenetic regulation of DNA repair. Molecules 2020, $25,2496$. [CrossRef] [PubMed]

149. Kim, J.H. Chromatin Remodeling and epigenetic regulation in plant DNA damage repair. Int. J. Mol. Sci. 2019, 20, 4093. [CrossRef]

150. Gong, F.; Miller, K.M. Histone methylation and the DNA damage response. Mutat. Res. 2019, 780, 37-47. [CrossRef] 